\title{
Development of a concept of an energy-efficient house for an environmentally friendly settlement in the South Ural
} \author{
and Azamjon Mahmudov ${ }^{1}$ \\ ${ }^{1}$ South Ural State University, Chelyabinsk, Russia \\ ${ }^{2}$ Komsomolsk-on-Amur State University, Komsomolsk-on-Amur, Russia
}

Sergey Gandzha ${ }^{1}$, Dilshod Aminov ${ }^{1, *}$, Bakhtiyor Kosimov ${ }^{1}$, Rustam Nimatov ${ }^{2}$, Azamdzhon Davlatov ${ }^{1}$

\begin{abstract}
Creation of comfortable housing for the population meeting the modern requirements of ecology, aesthetics, economical energy consumption and healthy lifestyle is a strategic task of any state. The world's leading countries have achieved significant results in this direction. In the context of economic sanctions, Russia will not be able to take advantage of the scientific achievements of foreign countries. In addition, our country has its own climatic features. Therefore, this strategic direction of development should be implemented independently. The project should go through several stages of development. At the first stage, all the necessary scientific research should be carried out. In the second stage, these scientific studies should find their engineering solutions. At the third stage, an industry for the production of such settlements should be established. This article attempts to formulate the basic requirements for the house, site and the most ecological settlement. The authors of the project consider this to be a very important initial stage of the project development.
\end{abstract}

\section{Introduction}

Currently in Russia there has been the construction of individual housing. It should be noted that this process is spontaneous. As a rule, under the building allocated plots, which carried out individual construction based on the financial capabilities of the developer. The result is a settlement that does not meet the requirements of ecology, aesthetics, economical energy consumption, the expected comfort of living, a healthy lifestyle. As a result, large financial resources are spent without achieving, as a rule, the main result: the creation of housing that meets modern human requirements (physiological, aesthetic, and psychological).

It is quite difficult to solve the problem of creating comfortable housing for a settlement of several dozen houses. This requires projects that comprehensively address the above problems.

One of the variants for such a project is an environmentally friendly settlement. It is a settlement, which is created for the organization of environmentally friendly space for people's lives, satisfying the requirements of aesthetics, physiological and psychological comfort [1-15].

The task is complicated by the fact that in order to reduce land flooding in the practice of hydropower construction in recent years [24-28], preference has been given to the construction of hydro systems with a

Corresponding author: dilshod-aminov-93@mail.ru relatively small capacity of the reservoir and, consequently, with a reduced possibility of regulating river flow. In these conditions, the necessary additional regulating capacity is proposed to be placed on side tributaries of a river, creating flood control facilities with uncontrolled bottom and surface spillways.

In contrast to the existing settlements, which are built on old technologies, in this project it is proposed to take as a basis a house containing all modern high-tech achievements [16-25]:

- landscape design, taking into account the peculiarities of the terrain;

- interior design of the house that meets the modern requirements of aesthetics;

- concept of a passive house, that is, a house with minimal energy consumption for heating;

- concept of an Autonomous house, that is, a house without a centralized supply of heat, electricity, water supply. Alternative energy sources and heat pumps are the source of heat and electricity;

- concept of a smart home, that is, a house of modern type, organized for living people with the help of automation and high-tech devices.

At the Department of "Theoretical foundations of electrical engineering" together with the faculty of Architecture and construction conducted scientific work on the development of such a project [26-30].

The result of the project should be working documentation on energy-saving house, which will be used after binding to a specific area for environmentally 
friendly settlements in the southern Urals and other regions.

This article discusses the basic requirements that the project must meet.

\section{Formulation of the Problem}

Let us formulate the General requirements which must be met by the project.

The settlement should consist of plots that will be converted into ancestral estates of living families and their descendants in close harmony with nature, ecological farming and Autonomous ecological houses.

Basic requirements to the ancestral estate

* The design of the whole estate should be beautiful, comfortable and functional.

* The house should be energy-saving, environmentally friendly, Autonomous from the General water supply, Sewerage and electricity.

To create a natural system capable of self-regulation requires an area of at least 1 hectare per plot.

Along the perimeter of the plot is planted a hedge that will protect the site from noise, water and wind erosion, creating a favorable microclimate for the entire site.

An important element of agrobiocenosis is a garden with fruit plantations. Under this area should запланировать10 -20 acres.

It is necessary to plan 10-20 acres under the garden , which will be cultivated annual and perennial crops,

On the plot of 1 hectare, to create a favorable microclimate for most plants, it is necessary to provide a pond with a water mirror of 1.5-3 acres and a depth of 1.5-3 meters. At these sizes, a stable aquatic ecosystem with plants, fish and birds can be formed, which requires almost no maintenance. The pond increases humidity, which contributes to better plant growth and prevents them from burning out in drought, and in spring frosts significantly reduces the shedding of flowers, attracts birds and animals. It improves the aesthetic appearance of the site and is also used for irrigation of crops, fish farming. The total area of the reservoir and the surrounding area should be 4-6 acres.

\section{Requirements for The energy - efficient house}

Based on the concept of the ancestral estate, the house should accommodate three generations ( the older age is about 2 people, the average age is about 3 people, the younger generation is about 4 people), the total number of 9-10 people. For these persons should be provided comfortable accommodation (bedrooms, living room, dining room, sanitary facilities).

The house should be with low consumption of necessary resources, meet the requirements of aesthetics and comfort. The price of a house should be affordable for most of the population.

It should provide for the use of the following systems.
1. Ecological systems of energy self-sufficiency. For energy self- sufficiency, it is planned to apply:

- wind power plant $10 \mathrm{~kW}$. The wind turbine is planned to be placed at some distance from the house based on the requirements of landscape design;

- solar panel ;

- storage of electricity from batteries or fuel cells (located in the house).

All sources are included in the uninterruptible power supply system.

2. Provision of water resources. The source of water supply is a well. Water supply is carried out by means of an electric pump.

3. Provision of heat energy. Heat supply must comply with the concept of a passive house (15 $\mathrm{kWh} / \mathrm{m} 2$ per year, for its functioning (heating and cooling) the Source of heat energy is heat pumps.

4. Ventilation. This system should provide a comfortable environment in all seasons of the year.

5. Lighting. The project provides for the use of natural light and economical lamps.

6. The system of biological waste processing.

7. Computer system smart home, which should provide a rational and energy-efficient use of heat, electricity, water, light.

\section{The basic principles to be observed in the establishment of the settlement}

We list the landscape planning requirements for the project:

- correct orientation of the building to the cardinal points;

- wind protection of the Northern blind side of the building, the closeness of this side: green spaces, forest, other building, etc.;

- open volume of the building from the South, no shading of the southern facade.

The space-planning requirements include the following requirements:

- maximum compactness of the building. This refers to the ratio of the area of enclosing structures and the entire volume of the building. The smaller the area of enclosing structures in relation to the usable area of the building, the more compact it is;

- zoning, i.e. the division into the buffer and residential areas;

- the location of the auxiliary areas of the North as a buffer zone;

- location of the residential area in the South-East;

- location of winter gardens on the South side;

- the presence of outdoor summer sun protection in the form of protruding architectural elements: cornices, balconies, terraces, shading translucent structures and do not let the rays of the high summer sun into the building.

Below are the requirements for the façade:

- lack of parts through which heat would leave the building, on its Northern side;

- location from the South of the maximum number of transparent structures that would pass deep into the building low rays of the winter sun; 
- Windows and other transparent structures should be located on the facade in the following ratio: $70-80 \%$ of all Windows on the South side, $20-30 \%$ on the East, $0-10 \%$ on the West and their complete absence from the North.

Energy-efficient house should be equipped with systems of accumulation of electric and thermal energy:

- the presence of massive accumulating elements inside the premises to ensure the reception, conservation and return of energy in places where direct sunlight from the low winter sun. Massive accumulating elements in this case should serve as a wall of solid brick or concrete;

- the use of clot-walls. Thrombus walls are designed to capture and accumulate solar radiation used to heat the air inside a heated building. The air circulation in the space between the glazing and the radiant surface is natural, with the air from each room coming out through the hole in the lower part of the wall, passes between the wall and the glazing up, and the already heated air returns to the room through the holes in the upper part of the heat-accumulating wall;

- planning of shallow rooms in which the low winter sun would fall on the back massive (preferably dark) wall, warming it up;

- massive elements inside the building (piers, internal parts of insulated external walls) also contribute to the passive accumulation of night cold in the building in the summer heat;

- capture by accumulating energy elements of "internal heat sources" (household appliances, human body, light bulbs, computers, etc.);

- high-quality external insulation of the outer shell of the building: complete insulation of all sides of the building: Foundation, walls, roof, etc.; By "quality insulation" refers to materials whose thermal conductivity should exceed $0.15 \mathrm{~W} /(\mathrm{m} 2 \mathrm{hk})$. The thermal conductivity of Windows and other translucent structures should not exceed $1 \mathrm{~W} /(\mathrm{m} 2 \mathrm{hk})$;

- high-quality thermal insulation material: its coefficient of thermal conductivity, the level of vapor resistance and heat-reflecting properties, the required thickness of the insulation layer;

- the quality of the application of insulation: no gaps between its parts, parts, joints, fuses, seams; no heat bridges (checked by thermography, using a thermal imager);

- the maximum possible tightness (airtightness) of the outer shell of the building.

- The house should fit into the surrounding landscape of the site and be part of the ecosystem, not an end in itself.

- Under the house and buildings allocated about 3-8 acres. Construction of the house begins after planting trees and determining the place for it.

- The house should have a garage for 3 cars. It is possible to place a garage in the volume of the house

- The landscape design should include a clearing for games. It serves children and adults for outdoor games, as well as to communicate with friends, animals and birds in the fresh air. One hectare is allocated for the field.

- A variant of the ecological settlement in the South Urals is shown in fig. 1.

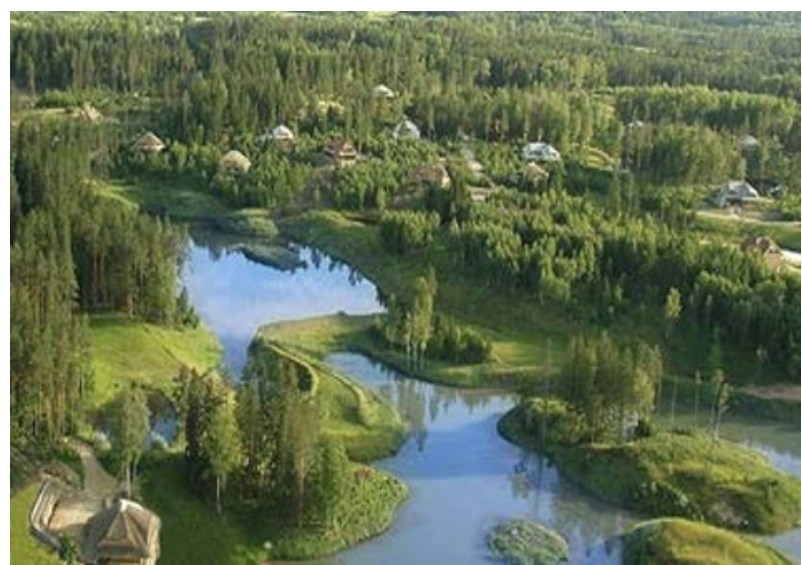

Fig. 1. Ecological settlement in the South Urals.

\section{Discussion}

The peculiarity of the project is that all formulated tasks should be solved in a complex. If you fulfill some of the requirements and do not fulfill other requirements, the main goal of the project will not be achieved. For example, you can make an expensive interior in the house, but not to solve the problem of landscape design. This will not create a comfortable living environment because most of the time the residents will be out of the house. Here is another example. The house will not be equipped with a resource system.

In this case, heat, electricity and water supply will require centralized systems. They disrupt the landscape design and comfortable living environment.

The implementation of the project has a serious problem. For a comprehensive solution to all problems will require large financial investments. In this case, such housing will be available only to a small part of the wealthy population. To solve this problem, it is necessary to create a powerful industry for the production of all components of such a settlement. In this case, the price will be low and affordable.This is a very difficult task, but such projects can be the engines of the development of the national economy.

\section{Conclusion}

The problem posed in the project covers a large number of technical problems. They have to be solved in a complex. The solution of only one technical problem, without solving another problem does not reach the final result.

The end result is the creation of housing that meets modern human requirements (physiological, aesthetic, psychological).

The project should go through several stages of development. At the first stage, all the necessary scientific research should be carried out. In the second stage, these scientific studies should find their engineering solutions. At the third stage, an industry for the production of such settlements should be established. It should be recognized that Russia lags behind the leading countries in the implementation of such projects, 
therefore, to accelerate the work on the project, it is necessary to make maximum use of international experience.

This article attempts to formulate the basic requirements for the house, site and the most ecological settlement. The authors of the project consider this to be a very important initial stage of the project development.

\section{Acknowledgment}

The work was carried out at the SUSU with the financial support of the Russian Science Foundation (project № 14-19-00327). The authors thank the officials for the opportunity to carry out this study.

\section{References}

1. B. K. Barker (2006)

2. M. Endhart (2010), pp.20-24.

3. S.A. Gandzha, D.S. Aminov, and B.I. Kosimov (International Conference on Industrial Engineering, Applications and Manufacturing ICOEAM, Sochi Russia 2019)

4. B. K. Review. (2005)

5. A. H. Buchanan, and B. G. Honey, (1994), pp. 205217

6. S.A. Gandzha, D.S. Aminov, I. E. Kiessh, and B.I. Kosimov (Global Smart Industry Conference, Chelyabinsk, Russia 2018)

7. H. Cleary (2007)

8. G. Hammond, and C. Jones (2006) .

9. Jenkins S (2008), pp.31

10. S.A.Gandzha, B.I. Kosimov, and D.S. Aminov (2019), pp.5-17

11. Lang, $N$ (1959)

12. Midlarsky, M.I (1997)

13. S.A. Gandzha, D.S. Aminov, and B.I. Kosimov, (Acta ex Perm national research Polytechnic University 2018) pp. 58-74

14. A. S. September (2004), pp. 7-8

15. N. Stern, (Cambridge: Cambridge University Press 2007)

16. G. Sergey, D. Aminov, and K, Irina. (International Conference on Industrial Engineering, Applications and Manufacturing ICIEAM Chelyabinsk, Russia 2018)

17. Town and County Planning Association (2007a)

18. Town and County Planning Association (2007b).

19. Town and Country Planning Association (2007c)

20. L. Vukotic, (2008)

21. S.A. Gandzha, D.S. Aminov, and B.I. (International Ural Conference on Green Energy UralCon Chelyabinsk, Russia 2018), pp.282-287

22. D. Aminov, B. Kosimov, and R. Nigmatov (2018), pp. $70-75$

23. S. A. Gandzha and I. E. Kiessh (2015), pp. 731-735

24. Mukhutdinov I. N., Orlov G. A and Kondrashin V. V. (International scientific research journal 2013), pp.84.

25. S. A. Gandzha, A. I. Sogrin, and I. E. Kiessh, (Procedia Engineering 2015), pp. 408-414
26. I. V. Kralina., E. V. Sheshunova and I. L. Greek (2014)

27. A. S. Martyanov and N. I. Neustroyev. (Alternative energy and ecology 2014), pp. 47-52

28. S. Gandzha, B. Kosimov and D. Aminov (Machines 2019)

29. A. A. Voloshinskaya and V. M. Komarov, (2017), pp.92-107

30. S. Gandzha, B. Kosimov, and D. Aminov, ( International Ural Conference on Electrical Power Engineering, UralCon Chelyabinsk, Russia 2019) 